\title{
Effect of Organisational Culture on Customer Satisfaction in Selected Nigerian Banks: Evidence from Multiple Age Bands
}

\author{
Abbas Umar Ibrahim, $\mathrm{PhD}^{*} \quad$ Anamege Anthonia Obianuju \\ Department of Business Administration, Nile University of Nigeria, Jabi District, Abuja, Nigeria
}

\begin{abstract}
This study investigated the extent to which technology-banking culture impacts on customer satisfaction with age cum generational differentials as moderating factor. A Likert-type survey was administered, via convenience sampling, to customers of Zenith Bank, First Bank, Fidelity Bank, Guarantee Trust Bank and Access Bank at the corporate headquarters of the Nigerian National Petroleum Corporation (NNPC). 300 copies of the survey were distributed while 259 customers responded, representing $86.3 \%$ of the administered instrument. Data was analyzed using descriptive statistics. Findings revealed that customers across all age categories gain significant satisfaction from tech-banking culture. However, compared to younger customers, older customers are practically more inclined to face-to-face (FTF) banking. Both the younger tech-savvy generation and the older techno-phobic generation are equally dissatisfied with the use of automated helpdesks. It was recommended that other Nigeriabased businesses, inclusive of government parastatals and establishments, should fully adopt technology-driven systems and processes towards earning Nigeria a better technology-compliance status as an upcoming economy provided that they also eliminate automated machines and leverage on humans for the delivery of helpdesk services. Keywords: Organizational Culture, Customer, Customer Satisfaction
\end{abstract}

DOI: $10.7176 / \mathrm{EJBM} / 11-18-01$

Publication date:June $30^{\text {th }} 2019$

\section{Introduction}

Profit making is the fundamental strategic intent of every business whether such profit is monetary or nonmonetary and irrespective of the type, size or location of the business. In essence, a business is deemed successful to the extent that desired profit is accrued within set time limits. Customer satisfaction is the most critical performance indicator that underscores profitability. Only satisfied customers exhibit brand loyalty and commitment, and only then can a business be sure of competitive advantage and its resultant profitability. Customers can only gain satisfaction if they are consciously indulged by the organization whether in terms of the quality of product or service for which they pay money or on account of the intangible, psycho-social experiences from the organization's customer relationship management efforts. Customer relationship management is in itself a factor of business values systems or organizational culture. Diverse organizational cultural elements directly affect employees, and where positive, they snowball into customer satisfaction, resource conservations and such positive relationships with customers that support increased return on investment (Musanzikwa \& Ramchander, 2018). In the same vein Madhani (2018, p46) posited thus: "The major distinguishing feature in highly successful organizations and their most important competitive advantage is their organizational culture".

Summarily, profit is a key factor of customer loyalty, which is determined by the level of customer satisfaction. Customer satisfaction is prompted by the quality of product and service delivery as well as the modus operandi of an organization and its culture. By inference, organizational culture is critical to the extent that it can enhance or undermined return on investment (ROI). Given the purported criticality of organizational culture in the actualization of business goals, this study is aimed at ascertaining how it enables or disables the satisfaction of customers across five banks located within the corporate headquarters of the Nigerian National Petroleum Corporation (NNPC) in Abuja, Nigeria's capital city.

The study subsequently consists of a statement of the problem, research objectives and research questions, which will provide direction towards addressing the key concerns of the study. An inclusive review of related literature discusses the conceptual, empirical and theoretical frameworks relative to the dependent and independent variables. Data analysis and discussion of findings are done alongside their implications and potential significance. Key recommendations are made in the interest of the banking sector, the government and other relevant stakeholders. Opportunities for further research are also highlighted.

\subsection{Statement of the Problem}

In a bid to increase return on investment, best organizations pay more attention to maintaining their share of customers and increasing customer loyalty in lieu of chasing after new customers, and part of their strategies towards achieving this feat is ensuring that customers enjoy $360^{\circ}$ satisfactions. The evolution of the technologyculture in banking is targeted at increasing the perceived value of banking services and achieving some measure of satisfaction for customers especially by way of relieving them of the stress and inefficiencies that defined their past banking experiences. Automated Teller Machines (ATMs), Point of Sale (POS) terminals and other 
technologies afford customers the luxury of convenient 24-hour self-paced banking, and this has added value to customer satisfaction on a global scale (Adeyemi \& Oyewole 2014). With the prevalence of the global economy, individuals, business and governments are obliged and committed to aligning with global technological trends, and the electronic banking culture is a key enabler in this regard (Ogunlowore \& Oladele, 2014). Because technology has become a critical global subject matter, it is easy and almost conventional to believe that most bank customers employ available banking technologies and are also positively impacted and satisfied by same, but this could be a harmful assumption.

According to Capioppo (as cited in Dongmo \& Onojaefe, 2013) individual differences account for perceived value and the level of satisfaction accruable from such value. People are different on the basis of age, level of education, socio-economic status, affordability of Wi-Fi network, without which the tech-banking tools cannot function efficiently, and these differentiating factors may also mean differences in the level of satisfaction that tech-banking culture can offer. The manner in which each individual is comfortable with the use of technology is relative, and the choice of doing technology-enhance banking is highly subjective (Couto, Tiago \& Tiago 2013). By virtue of education, generational value systems and exposure, younger generation Nigerians are stereotypically adjudged more tech-savvy than older citizens who are seen as mainly techno-phobic. In essence, all age categories may not be equally satisfied by the prevalent culture of technology as offered in the banking space in which case there may be need to make relevant adjustments in the adoption of tech-culture to create more satisfaction for needful age populations. Much has been done to ascertain how banking technology has impacted on Nigerian customers generally, but not much attention has been paid to how this subject matter plays out along age and generational divides in the Nigerian setting. Narrowing this knowledge gap holds some benefits for Nigerian banks and other local businesses.

\subsection{Research Objectives}

At the end of this study we aimed to determine:

- If younger bank customers are more satisfied using ATM Cards for POS/online purchases and doing internet banking transactions than older customers.

- If older bank customers are more satisfied going to banks in person for face-to-face (FTF) transactions than younger customers.

- If younger bank customers gain more satisfaction interacting with automated customer service helpdesks than older customers.

\subsection{Research Questions}

The following research questions evolve from the foregoing objectives:

- Are younger bank customers more satisfied using ATM Cards for POS/online purchases and doing internet banking transactions than older customers?

- Are older bank customers more satisfied going to banks in person for face-to-face (FTF) transactions than younger customers?

- Do younger bank customers gain more satisfaction interacting with automated customer service helpdesks than older customers?

\section{Literature Review}

Diverse conceptual perspectives of organizational culture have been put forward although there is no commensurate realization of definitive unison. The concept of organisational culture can be viewed from diverse perspectives in terms of the distinct culture elements that define this independent variable:

\subsection{Conceptual Framework: Organisational Culture (OC)}

Organisations are human metaphors in view of the fact that they consciously or subconsciously display peculiar behavioral patterns and uphold distinct value systems that define their brand or corporate personalities. Given the criticality of organisational culture to the realization of the bottom-line in business, the study of organizational culture has enjoyed enormous attention. McDougall and Ronkainen, (2019) observed that the concept of organizational culture has defied time and has been a persistent feature of the body of business literature while also holding such value proposition that makes it a near-indispensable subject of discourse.

\section{Subconsciously Emplaced Culture Elements}

Some studies view the concept of organisational culture from the standpoint of subconsciously established norms. Organisational culture is the sets of collectively held philosophies, codes of behavior, mode of operations and legitimate cum acceptable actions which, like an adhesive, binds organizational members into a collective whole with clear-cut uniform ways of doing things in the work environment (Wagner, Mannion, Hammer, Groene, Arah, Dersarkissian, \& Suñol, 2014). Culture reflects the value systems that people hold in their minds as necessitated 
by the unwritten and oftentimes unspoken principles which guide behavior and defines conventions within an organization (Davis \& Cates 2018). Thus conventions evolve from subconscious everyday organizational activities the violation of which triggers some kind of systemic reaction against what is considered an anomaly.

\section{Consciously Emplaced Culture Elements}

Culture can however be consciously, emplaced by organistional leaders via written mission, espoused vision and established policies cum core values all of which are aligned with the strategic intent of the business. Along this trajectory, Shiua and $\mathrm{Yu}$ (2010) opine that organizational culture is a blend of common goals, operational philosophy, processes, procedures, ethics, dogmas, customs, rituals and emblems all of which define the pattern of an organization's everyday business operations. In the same vein, Mccarthy (2015) holds that organizational culture constitutes of the acceptable ideas, processes, structures, systems, technologies and skill sets that leaders employ with a view to ensuring strategic performance. Irrespective of quality, a business strategy can be undermined by wrong organizational culture whereas a healthy organizational culture supports strategy towards yielding the desired results. Culture is thus an enabler and a tool for organizational goal actualization.

\section{Taken-for-granted Culture Elements}

Other schools of thought capture additional elements that define organisational culture. Lukasik, (2018) posits that culture elements also include other internal organisational factors such as the hierarchical structure cum organogram and other physical nitty-gritty of the organization. In this regard, seemingly unimportant factors are also part of what defines the culture of an organization. Corporate topography in terms of the environmental outlook, layout of offices, pattern of furnishing, work team methodologies (hierarchical or flat), workforce demographics, artifacts and even the colour of the walls in an organization all say something about its culture. In essence, features to which little or no importance are attached also add up to an organisation's cultural ambience. In the context of this study culture can be said to be the tangible and intangible components, lifestyle and mannerisms of an organisation and its members the totality of which defines its corporate brand and determines the extent to which its strategic goals can be actualized.

Although different studies have attempted different interpretations, the conceptual perspective of organisational culture is generally dependent on the ambience or approach of an intended study. (Sun, 2008). In aligning with this school of thought this paper adds three dimensions of culture to the body of literature: existential culture (the physical characteristics of organizations; who they are and what physical features they possess), ethics culture (the value systems and conventions of an organisation) and operational culture (process, procedures and how organisations do what they do).

Technology-banking culture is not a subconscious evolution. It is rather consciously emplaced with a view to making the banking experience easier for customers, enhancing customer satisfaction, increasing customer loyalty and realizing the desired return on investment. This culture fits into the ethics and operational dimensions of culture as it has over time become a critical part of the banking sector's acceptable value systems, conventions and processes adopted with a view to enhancing business efficiency.

\section{Customers}

Every organization maintains some measure of relationships with diverse categories of stakeholders who either affect or are affected by its everyday activities. Customers are the most critical part of such stakeholders, and the import of the concept of customers has been widely addressed. Most research studies view customers as the teaming external members of organisations (Korschun, 2015; Vough et al., 2013) as cited in (Cardador \& Pratt, 2018). Customers are those people who show commitment towards the continuous purchasing of goods and services from a business or market brand with a view to ensuring their own personal gratification (Khadka \& Maharjan, 2017). In alignment with the notion that customers buy products and services, Kumar (2013) adds that they also share their experiences with prospects in which case they also act as subconscious sales representatives. The foregoing viewpoints apparently consider customers to be same as consumers. However, Olson (2018) sees this perspectives as restrictive while also positing that the focus on customer as someone whose payment for products and services helps to sustain the business undermines a critical import of the terminology. He argues that 'customer' additionally means anyone with whom an organisation has to transact business in a bid to achieve its bottomeline. In other words staff, contractors, and dealers are also customers of sorts, and though they are not a direct source of revenue for the business, they indirectly impact on profit - making in very significant ways.

We conceptualize 'customer' as that individual who maintains an exchange relationship with an organization's brand to the extent that such commitment supports business success and sustainability. If the customer continues to patronize a business, it thrives, and where otherwise, the business ceases to be a going concern. 
Customer Satisfaction

Product and Service -induced customer satisfaction

Customer satisfaction is the degree to which a product or service adds value in a manner that either meets or exceeds the expectations of a customer (Mei1 \& Foosiri, 2018). In the same vein, Tigor, and Milawati (2018) defined customer satisfaction as the result of post-consumption evaluation in which a preferred product or service measures up or offers value that is far above the customer's expectation. By implication, customer dissatisfaction is feasible where the said alternative does not meet customer expectations. The customer is then disappointment in which case money invested in the purchase of the good or service may be considered a waste and patronage also regretted. Customer satisfaction is not a blanket concept and cannot be objectively defined without some consideration for individual differences. It is a subjective construct to the extent that what satisfies one customer may dissatisfy another. Kotler and Armstrong (2010) opine that customer satisfaction is relative in terms of its dependency on perceived value and how it aligns with the buyer's needs and expectations as an individual. Because customer satisfaction can be a very peculiar evaluation prejudiced by individual value systems and expectations, many explanations of the concept are based on the belief that individual customer expectation is the key determinant of consumer satisfaction or dissatisfaction as the case may be (Capioppo, as cited in Dongmo \& Onojaefe, 2013).

\section{Relationship-induced customer satisfaction}

Modern marketing approaches have explored additional strategies in a bid to increase customers' perceived value of product or service brands. Customer relationship management is one of such strategies. It establishes, develops and sustains rapport with customers to the extent that they are almost emotionally involved with a brand on account of the extra goodwill extended to them by the brand owner. Customer satisfaction is no longer solely prompted by the delivery of best goods and services. According to Kotler and Armstrong (2010), customer satisfaction is also a factor of quality of relationship that a business maintains with customers in the course of value delivery especially relative to meeting their purchasing needs. In the same vein Santouridis and Veraki, (2017) posited that goal realization in today's business terrain is significantly dependent on the quality of relationship that a business builds and maintains with its customers. Summarily, amidst tough competition in a business world where so many products and services are begging the loyalty of relatively the same market segments and target markets, brand decisions are influenced more by the level and quality of relationship-induced customer satisfaction than they are by product and service-induced satisfaction.

In context, customer satisfaction is the extent to which individual customers consider their known and unknown needs met not only by virtue of the quality of products or services offered for consumption, but also by the virtue of how they value their relationship with a business brand. The concept of customer satisfaction is thus a complex correlation between the perceived value of three distinct constructs (product, service and relationship) and the needs cum expectations of the customer. If the value proposition of both product, service and relationship align with customer needs and expectations, the customer is satisfied; if not, there is the probability of satisfaction or dissatisfaction. Where perceived value is higher than needs and expectations, there is satisfaction and consequent customer delight. Where expectations are higher than perceived value, there is customer dissatisfaction.

In aligning with the school of thought that considers the individual's perceived value as a key determinant of customer satisfaction, it is therefore erroneous to assume a generic standpoint as it concerns the degree to which bank customers gain satisfaction from tech-banking culture. The young, the old, the educated, the uneducated and people in different socio-economic strata of society may be uniquely motivated to derive diverse levels of satisfaction from the use of banking technologies.

\section{Theoretical Framework}

There are several theories on organisational culture and customer satisfaction, but this study is significantly aligned with Abraham Maslow's Theory of Human Needs. Humans are motivated and satisfied when their needs are met along five distinct classifications: physiological, safety, affiliation, esteem and self-actualization needs (Maslow, 1943). Physiological needs include food, water, sleep and other sensory desires. Safety needs are needs for security whether physical or psychological. The need for affiliation explains the fact that every human being needs love and acceptance. Esteem needs address the desire for accomplishments and achievements while self-actualization needs seek to satisfy the inherent human tendency towards attaining ones most feasible potential (Miller, 2012). Customer satisfaction is driven by the ability of an organization to address the needs of its customer's to the extent that it is totally unrealistic if human needs are unmet by the value proposition offered by a product or service brand. From its purview of needs gratification, Maslow's theory situates the reality about how much the technology culture in the banking market place helps banks to meet the physiological, safety, affiliation, esteem and selfactualization needs of customers in diverse age categories with a view to achieving customer satisfaction across board. 


\section{Empirical Review}

Technology-enhanced banking is strategic to customer satisfaction, business growth and by extension, national development. Interestingly, the measure for national development is gradually drifting away from calculations of gross domestic product (GDP). The extent to which citizens can employ technology in their daily living addresses their individual developmental needs and indirectly adds value to the speed of national development (Bankole 2017). A plethora of research have been conducted to establish relationship between technology-enhanced banking culture and customer satisfaction, and so much empirical evidence exits which support the stance that there is a positive correlation between the two variables. In a study aimed at examining the significance of mobile, online, and face-to-face banking across various age categories, Michael, Cox, Musgrove and Ernstberger (2016) used factor analysis and analysis of covariance to evaluate data collected via a survey. Findings revealed that older bank consumers still have very positive value perception about one-on-one banking, but they are also as interested in online banking as younger people are while younger people themselves show greater flair for trending banking technologies than they do for one-on-one banking. However, the study tends to present a western ambience to the extent that the findings could be a peculiar narrative of the developed world where citizens are much more adept in the use of technology due to high literacy and numeracy and due to the availability of state-of-the-art technology infrastructure. We envision that customer satisfaction on account of the culture of technology may differ in the African environment.

A study by Amin, Onyeukwu and Osuagwu (2018) lends support to this standpoint. They investigated the influence of e-banking on service quality and customer satisfaction in designated Nigerian banks in addition to examining the factors affecting e-banking and customer satisfaction. A mixed method consisting of a structured questionnaire and interviews were used for data collection while descriptive statistics was adopted for data analysis. It was found that e-banking services have increased the efficiency of banking services but has had no substantial influence on customer satisfaction as evidenced by long queues which still characterize daily banking experiences in Nigeria in spite of the option of technological banking. Additional evidence were indicative of the fact that customers still prefer face-to-face banking due to poor network service, insecurity and power failure all of which limit customer preferences for the use of technology-enhanced banking methods.

Ogunlowore and Oladele (2014) tend to agree with this finding. They researched the effect of electronic banking on Nigerian bank customers in terms of how much satisfaction it affords them. A single structured survey was employed for collection of data which was analyzed via descriptive statistics. The hypothesis was tested using the Chi-Square test, and it was found that there is a substantial relationship between electronic banking and customer satisfaction. Findings also showed that e-banking has become popular because of its availability, convenience, speed and productivity although insecurity and poor power supply are key limitations to its efficiency.

Still within the purview of discovering how technological tools create satisfaction for bank customers, Addai, Ameyaw, Ashalley, and Quaye (2015) examined the effect of electronic banking service culture on customer satisfaction in Ghana along the dimensions of availability, reliability and convenience of banking technologies. SPSS 21 was used for data analysis. A multiple regression analysis was also done. The study found a positive correlation between customer satisfaction and e-banking provided that availability, reliability and convenience are assured.

Couto, Tiago and Tiago (2013) tend to disagree with the position that customer satisfaction is a sole factor of infrastructural efficiency as suggested by the foregoing studies. They researched Portuguese consumers' acceptance of the use of internet banking. Using an online "snowball" data collection methodology they found that the individual customer's level of comfort with the use of technology and the way technology is perceived affected the use of internet banking. In other words customers' perceived value of technological as a way of life and their personal attitude towards technology determine the extent to which they choose to patronize technology-enhanced banking and therefore determines accruable satisfaction from same. This finding demonstrates that customer satisfaction can possibly and equally be determined by other factors other than good technological infrastructure and facilitates. With sound infrastructure, all customers may still experience diverse levels of satisfaction or dissatisfaction with technology-enhanced banking. In essence, all things being equal, there are other feasible dimensions within which technology-induced customer satisfaction may equally be determined. Generational orientation towards technology is one of such dimensions.

\section{Methodology}

A mix method consisting of a questionnaire and unscheduled interviews were used for the data collection from customers of each of the selected banks through convenience sampling. The questionnaire had three key questions and was structured in a closed-ended form while also requiring respondents to indicate their age. A 5-scale Likert's response method was adopted and the responses were scored as presented in the table below: 
Table 1: Likert-Scale Table

\begin{tabular}{|l|l|l|}
\hline Response & Legend & Points \\
\hline Very Satisfied & VS & 5 \\
\hline Somewhat Satisfied & SS & 4 \\
\hline Undecided About & UA & 3 \\
\hline Somewhat Dissatisfied & SD & 2 \\
\hline Very Dissatisfied & VD & 1 \\
\hline
\end{tabular}

Source: Authors' Compilation, 2019

Three hundred copies of the survey instrument were distributed right within the banking halls of the five select banks during peak periods (shortly after the payment of salaries), at training classrooms and other corporate gatherings within the NNPC corporate headquarters. A grand total of 259 bank customers responded. Convenience sampling was also employed in the administration of unscheduled interviews using open-ended questions drawn from common response patterns in the structured questionnaire to ascertain if the pattern of response to the interview questions would align with the survey responses or make further disclosures. The unscheduled interviews caught respondents in their natural state and in the course of their normal everyday activities which enhanced the validity of feedback.

\section{Data Analysis}

Data was analyzed via descriptive statistics, specifically by computing the weighted mean score (WMS) of responses to each question by respondents from each age category. The mean score for each question is the summation of the product of the number of respondents to each question and the point(s) allocated to that category on the Likert Scale Table. This summation is then divided by the number of respondents to get the weighted mean score for that question.

Using the 5-point Likert scale, the WMS is calculated as:

$5+4+3+2+1=15$

$15 \div 5=3$

The mean score of 3 was therefore the criterion for decision. A mean that is 3 points or above was considered significant (positive) while any mean below 3 points was insignificant (negative).

Table 2: Summary of responses to survey questions and weighted mean scores (WMS) across all age categories

\begin{tabular}{|c|c|c|c|c|c|c|c|c|c|}
\hline Questions & Age & VS & SS & UA & SD & VD & Total & $\begin{array}{l}\text { WMS } \\
=/>\mathbf{3}\end{array}$ & Remark \\
\hline \multirow{8}{*}{$\begin{array}{l}\text { I am (?) using my } \\
\text { ATM Card for } \\
\text { POS/online purchases } \\
\text { and doing internet } \\
\text { banking transactions }\end{array}$} & $20-$ & 83 & 25 & 4 & 2 & 4 & 118 & \multirow[b]{2}{*}{4.53} & \multirow[b]{2}{*}{ Positive } \\
\hline & 35 & $70.3 \%$ & $21.2 \%$ & $3.4 \%$ & $1.7 \%$ & $3.4 \%$ & $100 \%$ & & \\
\hline & \multirow{2}{*}{$\begin{array}{l}36- \\
45\end{array}$} & 50 & 17 & 1 & 3 & 0 & 71 & \multirow[b]{2}{*}{4.60} & \multirow[b]{2}{*}{ Positive } \\
\hline & & $69.9 \%$ & $23.9 \%$ & $2.0 \%$ & $4.2 \%$ & $0 \%$ & $100 \%$ & & \\
\hline & \multirow{2}{*}{$\begin{array}{l}46- \\
55\end{array}$} & 21 & 9 & 0 & 1 & 1 & 32 & \multirow[b]{2}{*}{4.50} & \multirow[b]{2}{*}{ Positive } \\
\hline & & $65.63 \%$ & $28.13 \%$ & $0 \%$ & $3.12 \%$ & $3.12 \%$ & $100 \%$ & & \\
\hline & \multirow[b]{2}{*}{$55>$} & 24 & 6 & 2 & 4 & 2 & 38 & \multirow[b]{2}{*}{4.21} & \multirow[b]{2}{*}{ Positive } \\
\hline & & $63.16 \%$ & $15.79 \%$ & $5.26 \%$ & $10.53 \%$ & $5.26 \%$ & $100 \%$ & & \\
\hline \multirow{8}{*}{$\begin{array}{l}\text { I am (?) going to my } \\
\text { bank in person for } \\
\text { face-to-face (FTF) } \\
\text { transactions }\end{array}$} & \multirow{2}{*}{$\begin{array}{l}20- \\
35\end{array}$} & 27 & 12 & 9 & 48 & 22 & 118 & \multirow[b]{2}{*}{2.78} & \multirow[b]{2}{*}{ Negative } \\
\hline & & $22.9 \%$ & $10.2 \%$ & $7.6 \%$ & $40.7 \%$ & $18.6 \%$ & $100 \%$ & & \\
\hline & \multirow{2}{*}{$\begin{array}{l}36- \\
45\end{array}$} & 33 & 7 & 7 & 20 & 4 & 71 & \multirow[b]{2}{*}{3.63} & \multirow[b]{2}{*}{ Positive } \\
\hline & & $46.51 \%$ & $9.85 \%$ & $9.85 \%$ & $28.16 \%$ & $5.63 \%$ & $100 \%$ & & \\
\hline & \multirow{2}{*}{$\begin{array}{l}46- \\
55\end{array}$} & 18 & 10 & 3 & 0 & 1 & 32 & \multirow[b]{2}{*}{4.38} & \multirow[b]{2}{*}{ Positive } \\
\hline & & $56.25 \%$ & $31.25 \%$ & $9.38 \%$ & $0 \%$ & $3.12 \%$ & $100 \%$ & & \\
\hline & \multirow[t]{2}{*}{$55>$} & 23 & 7 & 3 & 2 & 3 & 38 & \multirow[b]{2}{*}{4.18} & \multirow[b]{2}{*}{ Positive } \\
\hline & & $60.52 \%$ & $18.43 \%$ & $7.89 \%$ & $5.27 \%$ & $7.89 \%$ & $100 \%$ & & \\
\hline \multirow{8}{*}{$\begin{array}{l}\text { I am (?) speaking with } \\
\text { a human customer } \\
\text { service representative } \\
\text { instead of automated } \\
\text { helpdesk machines }\end{array}$} & \multirow{2}{*}{$\begin{array}{l}20- \\
35\end{array}$} & 66 & 28 & 15 & 9 & 0 & 118 & \multirow[b]{2}{*}{4.28} & \multirow[b]{2}{*}{ Positive } \\
\hline & & $55.9 \%$ & $23.8 \%$ & $12.7 \%$ & $7.6 \%$ & $0 \%$ & $100 \%$ & & \\
\hline & \multirow{2}{*}{$\begin{array}{l}36- \\
45\end{array}$} & 47 & 11 & 4 & 5 & 4 & 71 & \multirow[b]{2}{*}{4.29} & \multirow[b]{2}{*}{ Positive } \\
\hline & & $66.19 \%$ & $15.49 \%$ & $5.63 \%$ & $7.06 \%$ & $5.63 \%$ & $100 \%$ & & \\
\hline & $46-$ & 26 & 2 & 2 & 0 & 2 & 32 & & \\
\hline & 55 & $81.25 \%$ & $6.25 \%$ & $6.25 \%$ & $0 \%$ & $6.25 \%$ & $100 \%$ & 4.56 & Positive \\
\hline & $55>$ & 22 & 11 & 4 & 1 & 0 & 38 & & \\
\hline & & $57.89 \%$ & $28.95 \%$ & $10.53 \%$ & $2.63 \%$ & $0 \%$ & $100 \%$ & 4.42 & Positive \\
\hline
\end{tabular}

Source: Authors' filed work, 2019 


\subsection{Discussion of Findings}

The older generation in this part of the world is commonly stereotyped as outrightly technophobic while the younger generation is perceived as more tech-competent. Consequently common assumptions are that the younger generation is more capable of thriving in technology-related activities and enjoying satisfaction from such activities than the older generation. Interestingly, this study found that more customers across all the studied age categories are technology-competent enough relative to banking. They all gain more satisfaction doing online banking and using Automated Teller Machine (ATM) cards for online and Point of Sale (POS) transactions than they do from face-to-face (FTF) banking. Relative to this subject, respondents demonstrated a Weighted Mean Score (WMS) of $>3$ across all age categories $(4.53,4.60,4.50$ and 4.21), as shown in Table 2, which implies that there is significant satisfaction across board. In terms of the level of satisfaction from FTF banking transactions, older customers demonstrated more satisfaction compared to younger customers. The WMS of older age categories (3.63, 4.38 and 4.18 ) buttress this when compared to the WMS of $\mathbf{2 . 7 8}$ for younger customers as also shown in Table 2. The foregoing lends support to findings by Michael et al (2016) from their North America-based study.

More than $50 \%$ of interviewees gave security and convenience as reason all age categories of customers are forced into accepting technology-enhanced banking culture although they also consider it very gratifying. However, an insignificant proportion of younger bank customers that were interviewed attested that the ease of ATM and POS transactions creates motivation of extravagance.

Feedback from about $80 \%$ of interviewees showed that older customers are not constrained by generational orientation nor are the uneducated constrained by their lack of formal education, the reason being that they subconsciously and informally receive technology education while also learning smart dispositions from younger or educated people within their immediate environment, and they are actually surprised at their own tech-banking abilities. Response patterns showed that a typical older bank customer is more reluctant to exercise his technologycapacity in the operation of a SMART television for instance than he is in operating his personal bank account, and this was attributed to the importance attached to money alongside the need for security and confidentiality in the management of personal finance.

With a WMS of 4.28, 4.29, 4.56 and 4.42, the respective age categories of customers are more satisfied speaking to human customer service representatives instead of listening to automated helpdesk machines. Although they are highly tech-savvy, younger customers are equally averse to interactions with automated helpdesks when they need to resolve problems or make enquiries from their banking service providers.

\section{Conclusion and Recommendations}

Age and seeming generational limitations do not actually constitute a setback to gaining satisfaction from technology-enhanced banking as tech-competency is somewhat contagious to the extent that older and illiterate citizens get comfortable with technology through informal education and by mere co-existence with the tech-savvy younger generation. Older customers are significantly tech-savvy in doing banking transactions than they care to be in other technology-enhanced activities.

The perception that the older and technophobic generation will not be able to cope with the emplacement of a full-blown technology-enhanced society is erroneous and should be discarded. Given that all generational cum age categories are significantly satisfied with a tech-driven banking culture, it is feasible that they will equally be able to transfer this competence and as much gain commensurate satisfaction from a wholesomely technologydriven society.

Diverse other business sectors inclusive of the Nigerian government should thus be confident to proceed with the full emplacement of tech-based systems and processes to facilitate the building of a technology compliance status for Nigeria as an upcoming economy.

Technology does not however create satisfaction for affiliation needs. All age categories of bank customers desire care, attention and outright assistance from human elements when they experience difficulties with their tech-banking transactions. To further enhance customer satisfaction in a comprehensive technology-regime, banks and other businesses should eliminate automation and leverage on real humans for the satisfactory delivery of helpdesk services.

\section{Areas for Further Research}

Beyond generational or age diversity, studies along the dimensions of other demographic differentials may change the narrative about the influence of tech-enhanced banking culture on customer satisfaction. Questions as to how habitat, religious inclinations or socio-economic status may moderate the impact of tech-banking culture on customer satisfaction are fertile opportunities for further research.

\section{References}

Addai, B., Ameyaw, B., Ashalley, E., \& Quaye, I. (2015). Electronic Banking and Customer Satisfaction: Empirical Evidence from Ghana. British Journal of Economics, Management \& Trade, 9 (3), 1-8 
Adeyemi O., Ola, O., \& Oyewole, F. (2014). Internet Banking Functionality in Nigeria and Outcomes of Customer Satisfaction: An Empirical Investigation. International Journal of Academic Research in Business and Social Sciences, 4 (8), 195-204

Amin H., Onyeukwu, P., \& Osuagwu, H. (2018). E-Banking, Service Quality and Customer Satisfaction in Selected Nigerian Banks. International Journal of Innovation and Economic Development, 4 (2), 51-57

Bankole, F. (2017). ICT Infrastructure and its Impact on National Development: A Research Direction for Africa. African Journal of Information Systems, 9 (2), 77-101

Cardador, M. T., \& Pratt, M. G. (2018). Becoming Who We Serve: A Model of Multi-Layered EmployeeCustomer Identification. Academy of Management Journal, 61 (6), 2053-2080

Couto, J., Tiago, T., \& Tiago, F. (2013). An analysis of Internet Banking in Portugal: the antecedents of mobile banking adoption. International Journal of Advanced Computer Science and Applications, 4 (11), 117-123

Davis, R., \& Cates, S. (2018). The implementation of the organizational culture assessment instrument in creating a successful organizational cultural change. International Journal of Business \& Public Administration, 15 (1), 71-94

Dongmo, C., \& Onojaefe D. (2013). Using customer satisfaction to understand implementation benefits of the ISO 9001 quality management system. Business Management Dynamics, 3(3), 01-09

Khadka, K., \& Maharjan, S. (2017). Customer satisfaction and customer loyalty (Thesis). Retrieved from the JURN database. (Order No. 161421179)

Kotler P., \& Armstrong G. (2010). Principles of marketing. New Jersey: Pearson Prentice Hall

Kumar, V. (2013). Profitable Customer Engagement: Concept, Metrics and Strategies. Thousand Oaks, California: Sage Publications

Łukasik, K. (2018). Mechanisms of changes of organisational culture in corporate environment. Organization \& management scientific quarterly, 3 (43), 81-93

Madhani, P. (2018). Enhancing customer value creation with market culture: Developing 7Cs framework. The IUP Journal of Management Research, 17(3), 46-64

Maslow, A. H. (1943). A theory of human motivation. Psychological Review, 50 (4), 370-396

McCarthy, S. (2015). Organisational culture - If you can 'see' it you can change it, Human Resources Magazine, 20 (3), 28-29

McDougall, M., \& Ronkainen, N., (2019). Organisational culture is not dead... yet, Sport \& Exercise Psychology Review, 15 (11), 13-19

Mei1, Y., \& Foosiri, P. (2018). Study of the relationship between marketing mix, service quality customer satisfaction and customer loyalty in the smart phone. UTCC international journal of business \& economics, $10(3), 79-102$

Michael, H., Cox, C., Musgrove, F., \& Ernstberger, W. (2016). Consumer preferences for banking technologies by age groups. International Journal of Bank Marketing, 34 (4), 587-602.

Miller, K. (2012). Organizational communication: Approaches and processes. Boston: Wadsworth Cengage Learning

Musanzikwa, M., \& Ramchander, M. (2018). The influence of dimensions of organisational culture on supply chain performance in selected state-owned enterprises in Zimbabwe. Journal of Transport and Supply Chain Management, 12(0). Retrieved March 12 ${ }^{\text {th }}$, 2019, from http://doi.org/10.4102/jtscm.V12i0.392

Ogunlowore, J. A., \& Oladele, R. (2014). Analysis of electronic banking and customer satisfaction in Nigeria. European Journal of Business and Social Sciences, 3(3), 14-27

Olson, A. B. (2018). Who is your customer? Industrial Management, 60(4), 28-30

Santouridis, I. \& Veraki, A. (2017). Customer relationship management and customer satisfaction: the mediating role of relationship quality. Total Quality Management \& Business Excellence, 28 (9/10), 1122-1133.

Shiua, Y., \& Yu, T. (2010). Internal marketing, organisational culture, job satisfaction, and organisational performance in non-life insurance. The Service Industries Journal, 30 (6), 793-809

Sun, S. (2008). Organizational culture and its themes. International Journal of Business and Management, 3 (12) $137-141$

Tigor, S., \& Milawati, Y. (2018). The influence of service quality and customer trust toward customer loyalty: the role of customer satisfaction. International Journal for Quality Research, 12 (3) 639-653

Wagner, C., Mannion, R., Hammer, A., Groene, O., Arah, A., Dersarkissian, M., \& Suñol, R. (2014). The associations between organizational culture, organizational structure and quality management in European hospitals. International Journal for Quality Healthcare, 26, 74-80 